\title{
Belas Kasih Diri (Self Compassion) pada Mahasiswa
}

\author{
Fahada Bagas Karinda ${ }^{1}$ \\ Fakultas Psikologi, Universitas Muhammadiyah Malang \\ e-mail: 1fahadabagas@gmail.com
}

\begin{abstract}
Academic demands, adaptation, and socialization were things that must be experienced by every student. Going by these demands made students have unstable emotions. Prolonged negative emotions with no resolution made difficult for students to develop themselves and tend to withdraw from the environment. To overcome negative emotions, an individual must be able to accept all the realities, weaknesses, and problems that occur, this term refers to self compassion. Self compassion is a compassionate attitude or behavior towards ourself when facing difficulties, to accept all suffer, self-deprivation, and every failure as part of life. The purpose of this study was to determine general description of self compassion in students. Subjects were 345 students of University of Muhammadiyah Malang. Convenience sampling was used as sampling technique with Self Compassion Scale as measuring instrument. The results of this study were analyzed using quantitative descriptive test and showed that level of self compassion of students based on gender had a slight difference, 52,7\% of men as well as 53,6\% of women both in high category.
\end{abstract}

KEYWORDS Self compassion, students

CITATION Karinda, F. B. (2020). Belas kasih diri (self compassion) pada mahasiswa. Cognicia, 8, (2). 234-252.

Pendidikan tinggi sangat erat kaitannya dengan kata mahasiswa. Mahasiswa sendiri diartikan sebagai sekumpulan kelompok di dalam lingkup perguruan tinggi yang berusia sekitar 18-30 tahun (Asiyah, 2013). Mahasiswa memiliki peranan penting sebagai pelaku perubahan karena mahasiswa sangat dekat dengan perkembangan ilmu pengetahuan. Hal tersebut sejalan dengan pendapat Winarno (2012) yang berpendapat bahwa mahasiswa mempunyai peran sebagai agen perubahan sosial seperti yang tercantum dalam tridharma perguruan tinggi (pendidikan, peneliti, dan pengabdian masyarakat). Sehingga mahasiswa akan selalu dituntut untuk melakukan perubahan-perubahan perilaku di dalam lingkungan.

Seorang individu yang memasuki dunia perkuliahan akan mengalami perubahan besar dalam hidupnya (Santrock, 2007). Perubahan yang dialami pada mahasiswa adalah berbagai fonomena yang disebabkan adanya masa peralihan dari remaja menuju masa dewasa (Hurlock, 2006). Mahasiswa memasuki masa dewasa awal atau dewasa dini menurut perkembangan hidup manusia akan sering muncul permasalahn seiring bertambahnya usia pada masa dewasa awal. Dewasa awal sering disebut juga dengan masa peralihan dari yang awalnya ketergantungan menuju masa kemandirian, mulai dari kemandirian ekonomi, kebebasan menentukan diri sendiri dan pandangan tentang masa depan yang lebih realistis. Oleh karena itu, berbagai tuntutan sering membelenggu mahasiswa dalam menyelesaikan studinya seperti tuntutan akademik, sosisalisasi dengan 
lingkungan kampus maupun lingkungan disekitar. Sehingga tidak awam lagi ditelinga kita sering mendengar berbagai berita yang meliput kehidupan mahasiswa mulai dari prestasi yang diperoleh, gambaran kehidupan kampus, hingga berita negatif seperti mahasiswa yang mengalami stres hingga bunuh diri. Selain itu perasaan depresi juga hal yang sering ditemui di kalangan mahasiswa Michael, Huelsman, Gerard, Gilligan, \& Gustafson (2006). Dari hasil penelitian Beck dan Young (1985) digambarkan tiga perempat dari seluruh mahasiswa merasakan depresi beberapa waktu pada masa sekolahnya. Keadaan ini dapat terjadi mengingat begitu kompleknya masalah yang menghadang mahasiswa ketika tengah menjalani studinya dan mengalirnya peluang mahasiswa mengalami simtom-simtom despresi dari berbagai masalah yang mungkin timbul. Seperti yang dijelaskan diatas tuntutan beradabtasi pada kondisi dan situasi lingkungan kampus, tugas yang menggunung, tuntutan akademik, dan lain-lain sangat mempengaruhi hal tersebut. Bahkan menurut Reifman dan Dunkel-Schetter (dalam Allgower Wardle, \& Steptoe 2001), simtom depresi dan kecemasan menjadi perhatian khusus pada mahasiswa, sekaligus dihubungkan dengan performansi akademik yang rendah dan partisipasi rendah dalam aktivitas kampus.

Penelitian yang dilakukuan oleh Asosiasi Kesehatan Universitas Amerika AKUA (2006) terhadap lebih dari 90.000 mahasiswa di 177 kampus mengungkapkan bahwa mahasiswa sering merasa tidak punya harapan, merasa kewelahan dengan hal yang harus mereka lakukan, mengalami kelelahan mental, sedih, dan merasa depresi adalah hal yang lazim dialami mahasiswa (Santrock, 2007). Hal tersebut merupakan hal yang wajar dialami oleh mahasiswa pada umumnya karena sebuah tuntutan didalam lingkungan kampus dan model pendidikan yang menuntutnya untuk melakukan suatu penyesuaian. Namun demikian tidak semua orang dapat menangani kondisi tersebut. American College Health Association-National College Health Assesment (ACHA-NCHA) pada tahun 2011 meneliti perjalanan mahasiswa dari tahun ke 2 hingga ke 4 diberbagai institusi di Amerika, mendapatkan hasil ada 30\% pada mahasiswa merasa tertekan dan hingga tidak tau ingin berbuat apa. Dari hal tersebut menjelaskan bahwa banyak mahasiswa yang merasa depresi namun kurangnya pengetahuan dalam cara mengatasinya membuat depresi yang dialami semakin besar (Krisdianto \& Mulyanti 2015).

Sementara di Indonesia sendiri pravelensi mengidap gangguan mental emosional seperti kecemasan dan depresi pada dewasa (termasuk dewasa awal) mencapai kurang lebih 1,74 juta orang. Mahasiswa juga termasuk di dalamnya, karena dari rentan usia mahasiswa yang menurut santrock (2007) mahasiswa masuk dalam fase dewasa awal. Selain itu di Indonesia dengan jumlah penduduk kurang lebih 1,33 juta jiwa diperkirakan mengalami gangguan kesehatan mental atau stres mencapai $14 \%$ dari total tersebut dan sekitar 1-3\% mengalami stres berat (legiran, Aziz, \& Bellinawati, 2015). Stres atau depresi terjadi pada berbagai tingkatan usia dan pekerjaan, termasuk juga mahasiswa. Di indonesia sendiri belum ada penelitian secara menyeluruh menggambarkan tentang angka mahasiswa yang mengalami depresi, namun masih bisa di ambil data secara bagian seperti dalam hasil kutipan dari penelitian Qonitatin, (2011) yang dilakukan pada 84 mahasiswa di kota Semarang diketahui 47 (55,95\%) diantaranya mengalami depresi dan ada 1 subjek yang cenderung mengalami deprisi yang cukup berat.

Penelitian lain yang dilakukan Cyinthia \& Anita (2009) subjek mahasiswa menjelaskan bahwa urutan pertama aspek depresi yang paling banyak dikeluhkan mahasiswa laki-laki maupun perempuan adalah menjadi mudah lelah. Pada urutan kedua mahasiswa laki-laki mengatakan tidak dapat bekerja sebaik waktu kemarin. Sedangkan urutan kedua pada 
mahasiswa perempuan cenderung cemas yang berkaitan dengan masalah fisik. Di urutan ketika mahasiswa perempuan maupun laki-laki merasa bahwa segala yang terjadi pada mereka adalah keadaan dimana mereka merasa sedang dihukum. Kejadian ini menununjukan pravelensi yang cukup menghawatirkan karena tentunya akan berpengaruh pada akademiknya dan juga pada pribadi mahasiswa sendiri. Penelitian tersebut juga merupakan suatu kondisi yang menggambarkan efek permasalahan yang dihadapi individu dan pada urutan ke tiga tersebut menggambarkan mahasiswa yang dihadapkan pada kondisi tertentu cenderung merasa kondisi tersebut adalah sebagai suatu hukuman. Namun akankah hal itu murni suatu hukuman atau hanya pemikiran negatif yang muncul atau dengan kata lain perasaan tersebut muncul akibat dari emosi-emosi negatif yang dipikirkan.

Dijelaskan oleh Halim (2015) hal yang menghambat seseorang untuk menjalani kehidupan salah satunya adalah emosi-emosi negatif yang berkepanjangan tanpa ada penyelesaian sehingga menjadikan seseorang tersebut sulit untuk mengembangkan diri dan cenderung menarik diri dari lingkungan. Untuk mengatasi emosi-emosi negatif tersebut seseorang harus dapat menerima segala dan kenyataan, kekurangan, dan permasalah yang terjadi padanya. Mempunyai sikap belas kasih diri menjadi gerbang awal dalam mengatasi emosi-emosi negatif yang dialami individu. Istilah ini disebut dengan belas kasih diri atau sering disebut dengan self compassion.

belas kasih diri (Self compassion) muncul dari kata compassion yang diturunkan dari bahasa Latin patiri dan bahasa Yunani patein yang berarti menderita, menjalani, atau mengalami. Self compassion merupakan konsep baru yang diadaptasi dari filosofi budha yang memiliki definisi secara umum adalah kasih sayang diri. Menurut Neff (2003), belas kasih diri didefinisikan sebagai sikap perhatian dan kebaikan terhadap diri sendiri saat menghadapi berbagai kesulitan dalam hidup ataupun kekurangan dalam diri. Belas kasih diri pada individu cenderung memiliki kasih sayang yang melibatkan diri sendiri seperti bersikap baik kepada diri sendiri dan bukannya mengkritik pada diri sendiri, tetapi lebih melihat penderitaan, kegagalan dan kekurangan sebagai bagian dari kehidupan manusia pada umumnya. Secara keseluruhan, itu mencakup pengakuan bahwa kelemahan dan kekecewaan adalah bagian dari pengalaman manusia dan setiap manusia akan mengalaminya, maka dari itu diri kita sendiri juga pantas menerima belas kasihan.

Menurut penelitian Martin dan Dahlen (2005) pemikiran negatif dapat memunculkan reaksi emosi yang negatif pada diri sesorang, seperti seseorang akan cenderung menyalahkan diri sendiri, menyalahkan orang lain maupun lingkungan sekitarnya. Dari hasil pemikiran tersebut akan menurunkan penilaian positif dan penerimaan pada situasi yang sedang dihadapi. Dalam keadaan seperti itu menyebabkan seseorang merasa kurang puas dan tidak bahagia pada kehidupannya. Berbagai pelampiasan emosi negatif salah satunya seperti makan makanan yang tidak sehat menjadi alternatif pilihan yang akhirnya menyebabkan penyakit. Berbagai dampak lain seperti merokok, minum minuman beralkohol, mengkonsumsi Junk Food, hingga bunuh diri. Mahasiswa yang stres dan juga memiliki emosi negatif akan berpengaruh pada nilai akademik dan kesehatannya Hudd (dalam seswita, 2013).

Dari gambaran diatas maka dapat disimpulkan mahasiswa akan mengalami berbagai macam permasalahan hal tersebut akan membuat guncangan pada mahasiswa. Permasalahan tersebut bermula dari tuntutan akademik dan lingkungan tempat mereka tinggal dimana ketika mahasiswa tidak dapat menjalankan tuntutan tersebut dengan baik 
maka akan muncul berbagai macam permasalahan seperti stres dan depresi dan ketika hal tersebut tidak di anulir dengan baik pula maka akan muncul dampak lain seperti performa akademik yang kurang hingga kegagalan akademik. Maka dari itu perlu untuk melakukan penelitian yang menjelaskan terkait gambaran dari belas kasih diri pada mahasiswa, sejauh mana mahasiswa mempunyai sikap belas kasih diri dan seperti apa peran dari sikap belas kasih diri seorang mahasiswa. Penggambaran tersebut membuat pengetahuan lebih dalam akan belas kasih diri sebagaimana adanya pada seorang mahasiswa. Dimana ketika melakukan suatu penggambaran akan mendapatkan gambaran umum dari fonomena tersebut sehingga dapat menjadikan literatur untuk peningkatan atau perawatan dari sikap seorang individu atau sebagai perencanaan strategi dari suatu instansi untuk meningkatkan performa peserta didiknya. Selain itu, dapat untuk meramalkan suatu fenomena kejadian yang akan datang maupun pencegahan pada dari suatu peristiwa negatif.

\section{Belas Kasih Diri (Self Compassion)}

Belas kasih diri (Self compassion) muncul dari kata compassion yang diturunkan dari bahasa Latin patiri dan bahasa Yunani patein yang berarti menderita, menjalani, atau mengalami. Belas kasih diri (Self compassion) merupakan konsep baru yang diadaptasi dari filosofi budha yang memiliki definisi secara umum adalah kasih sayang diri. Gilbert 2005 (dalam Halim, 2015) mendefinisikan compassion sendiri meliputi keinginan membebaskan diri dari penderitaan, kesadaran terhadap sumber dari penderitaan, dan perilaku perilaku yang menggambarkan kasih sayang.

Menurut Neff (2003), belas kasih diri didefinisikan sebagai sikap perhatian dan kebaikan terhadap diri sendiri saat menghadapi berbagai kesulitan dalam hidup ataupun kekurangan dalam diri. Belas kasih diri cenderung memiliki kasih sayang yang melibatkan diri sendiri seperti bersikap baik kepada diri sendiri dan bukannya mengkritik pada diri sendiri, tetapi lebih melihat penderitaan, kegagalan dan kekurangan sebagai bagian dari kehidupan manusia pada umumnya. Secara keseluruhan, itu mencakup pengakuan bahwa kelemahan dan kekecewaan adalah bagian dari pengalaman manusia dan setiap manusia akan mengalaminya, maka dari itu diri kita sendiri juga pantas menerima belas kasihan. Neff (2003) juga menjelaskan belas kasih diri sebagai alternatif konsep langkah untuk menuju individu yang sehat tanpa melibatkan evaluasi diri. Gagasan dari belas kasih diri memberikan jalan pemikiran alternatif bagaimana untuk melihat diri sendiri agar meningkatkan resiliensi pada individu. Memiliki belas kasih diri bukan berarti seseorang harus menjadi egois atau berpusat pada diri sendiri. Belas kasih diri berbeda dengan selfpity, ketika seseorang merasa self-pity ia akan merasa berada jauh dari orang lain dan lebih fokus melihat bahwa masalah yang dialami adalah yang paling berat dibandingkan orang lain (Neff 2003). Belas kasih diri adalah menghibur diri dan peduli ketika diri sendiri mengalami penderitaan, kegagalan, dan ketidaksempurnaan serta dapat mengambil makna dari kesulitan tersebut dan mengubahnya ke hal yang lebih positif (Hidayati, 2015).

Sedangkan menurut kutipan Gillbert dan Procter (2006), belas kasih diri lebih kepada sikap menenangkan diri ketika mengalami keadaan yang kurang baik atau keadaan yang tidak diinginkan. Perlakuan untuk diri sendiri dimulai dengan berhenti sejenak dari aktivitas dan memberikan istirahat secara emosional sejenak. Penguatan diri dilakukan juga dengan memberikan kata-kata positif yang dapat menyulut semangat dan penerimaan diri. Ditambahkan juga oleh Reyes (2011) bahwa belas kasih diri adalah kemampuan mencintai dan bermurah hati pada diri sendiri ketika dalam keadaan yang tidak menyenangkan. 
Kemudian menurut Werner, Jazaieri, \& Goldin (2012) self compassion merupakan sikap kepemilikan orientasi diri yakni lebih kepada penerimaan diri dan kepedulian terhadap diri sendiri. Sedangkan menurut Breines dan Chen (2012) mendefinisikan suatu kemampuan mengasihi diri meski ketika kondisi yang sedang dialami kurang baik.

Berpacu dari penjelasan tersebut, peneliti menyimpulkan belas kasih diri (self compassion) merupakan sikap atau perilaku kasih sayang pada diri sendiri ketika tengah menghadapi kesulitan dan memiliki pemikiran terbuka terhadap segala bentuk penderitaan, kekurangan diri, dan setiap kegagalan, karena semua itu adalah bagian dari kehidupan setiap manusia.

\section{Aspek-Aspek Belas Kasih Diri (Self Compassion)}

Neff (2003) mengembangkan alat ukur belas kasih diri yang sering digunakan untuk penelitian terkait belas kasih diri. Berikut merupakan enam aspek dari belas kasih diri menurut Neff (dalam Halim 2015), yaitu:

\section{Self-kindess vs Self-judgement}

Kemampuan individu untuk memahami dan menerima diri apa adanya serta memberikan kelembutan, tidak menyakiti atau menghakimi diri sendiri. Self-kindess membuat individu menjadi hangat terhadap diri sendiri ketika menghadapi rasa sakit dan kekurangan pribadi, memahami diri sendiri dan tidak menyakiti atau mengabaikan diri dengan mengkritik dan menghakimi diri sendiri ketika menghadapi masalah.

Self-judgement adalah kebalikan dari Self-kindess yaitu individu dengan Selfjudgement lebih menyerang atau menghakimi diri sendiri secara keras atas kekurangan maupun kegagalan yang dimiliki. Individu tersebut juga akan merendahkan dan mengkritik aspek-aspek dalam diri (Neff, 2003). Menurut Hidayati (2013) digambarkan ketika individu menolak pemikiran, perasaan, dorongan, tindakan, dan nilai-nilai diri sehingga menyebabkan individu merespon secara berlebih sesuatu yang terjadi pada dirinya.

\section{Common humanity vs isolation}

Common humanity adalah kesadaran bahwa individu memandang kesulitan, kegagalan, dan tantangan merupakan bagian dari hidup manusia dan merupakan sesuatu yang dialami oleh semua orang, bukan hanya dialami diri sendiri. Komponen mendasar kedua dari self compassion adalah pengakuan terhadap pengalaman manusia bersama. Common humanity mengaitkan kelemahan yang individu miliki dengan keadaan manusia pada umumnya, sehingga kekurangan tersebut dilihat secara menyeluruh bukan hanya pandangan subjektif yang melihat kekurangan hanyalah miliki diri individu. Begitupula dengan masa-masa sulit, perjuangan, dan kegagalan dalam hidup berada dalam pengalaman manusia pada keseluruhan, sehingga menimbulkan kesadaran bahwa bukan hanya diri kita sendiri yang mengalami kesakitan dan kegagalan di dalam hidup. Penting dalam hal ini untuk memahami bahwa setiap manusia mengalami kesulitan dan masalah dalam hidupnya.

Menurut Neff, (2009) individu yang merasa isolation (terisolasi) cenderung akan memiliki pandangan sempit pada kesulitan, tantangan, dan kegagalan sehingga akan berfokus pada ketidaksempurnaan diri. Individu tersebut juga akan merasa ketidak adilan karena kenapa hanya dirinya saja yang menderita dan mengalami penderitaan tersebut dan cenderung merasa dirinya paling menderita. 


\section{Mindfulness vs overidentification}

Mindfulness adalah melihat secara jelas, menerima, dan menghadapi kenyataan tanpa harus menghakimi terhadap apa yang terjadi di dalam suatu situasi. Menurut Brown \& Ryan, (2003) Mindfulness mengacu pada tindakan untuk melihat pengalaman yang dialami dengan perspektif yang objektif. Mindfulness diperlukan agar individu tidak terlalu terindenfikasi dengan pikiran atau perasaan negatif. Hidayati (2013) menjelaskan bahwa konsep utama mindfulness adalah melihat sesuatu seperti apa adanya, tidak ditambah tambahi maupun dikurangi, sehingga respon-respon yang dihasilkan dapat lebih efektif. Dengan mindfulness ini individu dapat sepenuhnya mengetahui dan mengerti apa yang sebenarnya dirasakan.

Overidentification adalah kebalikan dari Mindfulness yaitu sebuah reaksi berlebih dari individu ketika menghadapi permasalahan. Individu akan cenderung melebihlebihkan sesuatu yang dirasakan sehingga akan muncul kecemasan dan depresi. Dari hal itu Mindfulness akan bertugas mencegah individu melakukan over identification dengan metode perenungan keterbatasan diri.

\section{Faktor yang Mempengaruhi Belas Kasih Diri (Self Compassion)}

Menurut Neff, (2003) belas kasih diri dipengaruhi oleh beberapa faktor-faktor yang mempengaruhi, yaitu:

\section{Jenis kelamin}

Menurut Neff, (2003) wanita memiliki pemikiran yang jauh lebih penuh daripada laki-laki sehingga sering kali perempuan menderita depresi dan kecemasan lebih kompleks daripada laki-laki. Meski perbedaan gender dipengaruhi oleh peran tempat dan budaya namun sebuah penelitian menunjukan gambaran bahwa perempuan cenderung memiliki belas kasih diri sedikit rendah dari pada laki-laki. Hal tersebut terjadi karena perempuan lebih memikirkan mengenai kejadian negatif dimasa lalu. Oleh sebab itu, perempuan lebih cenderung memiliki depresi dan kecemasan lebih tinggi daripada laki-laki.

\section{Budaya}

Penelitian yang dilakukan pada negara Thailand, Taiwan, dan Amerika Serikat menunjukan perbedaan latar budaya mengakibatkan perbedaan derajat belas kasih diri. Markus dan Kitayama (1991) dalam Neff, Pisitsungkagarn, Hsieh (2008), menjelaskan bahawa masyarakat di Asia yang miliki budaya collectivistic cenderung memiliki self concept interdependent sehingga lebih menekankan pada hubungan orang lain, keselarasan dalam bertingkah laku, dan peduli pada orang lain. Sedangkan individu dengan budaya barat lebih ke dalam individualistic memiliki self independent yang bertekanan pada kemandirian, kebutuhan pribadi, keunikan individu dalam bertingkah laku. Karena pada belas kasih diri menekankan pada kesadaran akan common hummanity dan keterkaitan pada individu lain, dapat diasumsikan bahwa belas kasih diri lebih cocok dalam budaya yang menekankan pada interdependent daripada independent. Dari hal tersebut menunjukan negara Asia lebih memiliki belas kasih diri karena memiliki budaya yang collectivist dan bergantung pada orang lain, namun masyarakat dengan budaya Asia lebih mengkritik diri sendiri dibandingkan masyarakat dengan budaya barat sehingga derajat belas kasih diri pada budaya Asia tidak lebih tinggi dari budaya barat. 
Jika diartikan secara lepas, individualisme merujuk kepada masyarakat yang memiliki hubungan individu satu dengan lainnya tidak terlalu mengikat. Setiap individu akan menjaga diri sendiri dan keluarga mereka saja, seperti keluarga inti atau yang memiliki hubungan darah. Sedangkan pada masyarakat kolektivisme merujuk pada sebuah masyarakat dimana individu dari kecil atau lahir akan terus terintegrasi dengan kuat, bersatu dalam kelompok, dimana masyarakat sepanjang hidupnya akan melindungi satu sama lain.

Pada ciri individualisme maupun kolektivisme memiliki karakteristiknya masingmasing. seseorang dengan individulisme yang tinggi memiliki karakteristik lebih dimotivasi oleh preferensi diri termasuk kebutuhan dan hak diri, memberikan prioritas terhadap tujuan diri sendiri, dan memiliki fokus terhadap analisa rasional dari hubungan mereka dengan orang lain (Triandis, 1994, dalam Kacen \& Lee, 2002). Selanjutnya pada seseorang yang memiliki individualis ditandai dengan berbicara sesuai dengan apa yang dipikirkan yang mana merupakan karakteristik dari orang yang jujur, dan memiliki rasa interdependen yang cenderung rendah. Berbeda dengan ciri kolektivisme yang sering kali di dimotivasi oleh norma dan kewajiban yang diberlakukan oleh kelompoknya dan memberikan prioritas terhadap tujuan dari kelompok tersebut (Kacen \& Lee, 2000). Karakteristik pada budaya kolektivisme adalah keharmonisan dan konfrontasi antar anggota sebisa mungkin sangat dihindari.

3. Usia

Terdapat beberapa penelitian yang dilakukan Neff \& Vonk, (2009) bahwa belas kasih diri terasosiasi secara signifikan dengan tingkat usia. Keterhubungan ini dianalisis oleh Neff dengan teori tentang tahap perkembangan Erikson, yang menjelaskan bahwa individu akan mencapai tingkat belas kasih diri yang tinggi apabila telah mencapai tahap integrity karena lebih bisa menerima dirinya secara lebih positif.

\section{Kepribadian}

Salah satu yang turut berpengaruh terhadap adanya belas kasih diri pada individu adalah kepribadian dengan salah satu dari dimensi The Big Five Personality dipakai untuk menggambarkan. Berdasarkan pengukuran yang dilakukan oleh NEO-FFI, ditemukan bahwa self compassion atau belas kasih diri memiliki hubungan dengan dimensi neuroticism, agreebleness, extroversion, dan conscientiousness dari the big five personality. Extraversion memiliki tingkat motivasi yang tinggi dalam bergaul, menjalin hubungan dengan sesama dan juga dominan dalam lingkungannya. Pada kepribadian extraversion seseorang mudah termotivasi oleh tantangan dan sesuatu yang baru sehingga akan terbuka dengan dunia luar dan lebih bisa menerima diri sendiri. Agreeablesness berorientasi pada sifat sosial sehingga hal itu dapat membantu mereka untuk bersikap baik kepada diri sendiri dan melihat pengalaman yang negatif sebagai pengalaman yang dialami semua manusia (Missilliana, 2014). Concientiousness menggambarkan perbedaan keteraturan dan disiplin diri individu. Concientiousness mendeskripsikan kontrol terhadap lingkungan sosial, berpikir sebelum bertindak, sehingga seseorang dapat mengontrol diri dalam menyikapi masalah.

\section{Peran Orang tua}

Menurut Neff \& McGeehee, (2010). Individu dengan derajat belas kasih diri yang rendah kemungkinan besar memiliki orang tua yang kritis, berasal dari keluarga disfungsional, dan cenderung menampilkan kegelisahan daripada individu yang 
memiliki derajat belas kasih diri yang tinggi. Hasil penelitian menunjukkan bahwa individu yang tumbuh dengan orangtua yang selalu mengkritik ketika masa kecilnya akan menjadi lebih mengkritik dirinya sendiri ketika dewasa. Model perilaku orang tua yang sering mengkritik diri sendiri saat menghadapi kegagalan atau kesulitan akan menjadi contoh bagi individu untuk melakukan hal tersebut ketika mengalami kegagalan dan menunjukkan derajat belas kasih diri yang rendah.

\section{Manfaat Belas Kasih Diri (Self Compassion)}

\section{Emotional well being}

Menurut Neff, (2009) seseorang yang memiliki tingkat belas kasih diri yang tinggi akan memiliki tingkat kecemasan dan depresi lebih sedikit. Kunci dari self compassion atau belas kasih diri adalah rendahnya self-criticism. Self-criticism dikenal menjadi salah satu prediktor penting dari kecemasan dan depresi. Seseorang yang memiliki belas kasih diri menyadari ketika mereka menderita, baik terhadap diri mereka sendiri, dan mengakui keterhubungan mereka dengan semua orang. (Neff, Kirkpatrick, \& Rude, 2007).

Pada penelitian lainnya belas kasih diri dikaitkan dengan kebijaksanaan yang lebih tinggi dan kecerdasan emosional (Neff, Kirkpatrick, \& Rude, 2007), mengambarkan belas kasih diri merupakan cara bijaksana untuk mengatasi emosi yang sulit. Seperti belas kasih diri terlibat dalam perenungan dan berpikir pada penekanan yang lebih sedikit. Selain itu belas kasih diri juga menggambarkan memiliki keterampilan mengatasi emosi yang lebih besar, dan kemampuan memperbaiki emosi negatif.

Belas kasih diri juga hadir untuk mendukung keadaan positif yang lebih baik. Seperti belas kasih diri dikaitkan dengan perasaan keterhubungan sosial dan kepuasan hidup (Neff, 2003), Neff, Pisitsungkagarn, \& Hseih, 2008). Deci dan Ryan (1995) berpendapat sangat penting untuk kesejahteraan. Individu yang memiliki belas kasih diri cenderung mengalami lebih banyak kebahagiaan, optimisme, rasa ingin tahu, dan memberikan pengaruh positif daripada mereka yang kurang memiliki belas kasih diri (Neff, Rude, \& Kirkpatrick, 2007). Dengan membalut penderitaan seseorang dalam belas kasih diri akan muncul perasaan positif dan perasaan positif tersebut akan membantu menyeimbangkan perasaan negatif.

Penelitian Waskito, (2018) yang dilakukan pada mahasiswa Bimbingan dan Konseling di Universitas Kristen Satya Wacana menggambarkan mindfulness (salah satu aspek belas kasih diri) memiliki hubungan yang searah dengan kepuasan hidup mahasiswa yang artinya samakin tinggi mindfulness yang dimiliki maka semakin tinggi pula tingkat kepuasan hidup mahasiswa begitupun sebaliknya semakin rendah mindfulness maka semakin rendah pula kepuasan hidupnya. Sehingga dapat digambarkan individu yang memiliki self compassion akan memiliki kebahagiaan sehingga kepuasan hidup pada individu tersebut juga akan meningkat.

\section{Motivasi}

Penelitian dari yang telah dilakukan mendukung gagasan bahwa belas kasih diri lebih meningkatkan motivasi daripada kepuasan diri sendiri. Belas kasih diri juga memiliki hubungan terkait dengan inisiatif pribadi yang lebih besar dan keinginan mencapai potensi puncak seseorang (Neff, Rude, \& Kirkpatrick, 2007). seseorang yang memiliki belas kasih diri memiliki sedikit kecemasan dan terlibat dalam sedikit perilaku self-handicapping seperti penundaan terhadap tugas dibandingkan mereka yang tidak memiliki belas kasih diri. 
Belas kasih diri berhubungan positif dengan tujuan serta penguasaan motivasi intrinsik untuk belajar dan tumbuh (Neff, 2005). Sehingga, belas kasih diri membuat individu termotivasi untuk lebih giat dan sukses. Pada jurnal Juliana G. Breines dan Serena Chen mengenai self-compassion increases self-improvement motivation pada mahasiswa dijelaskan bahwa belas kasih diri dapat meningkatkan motivasi dalam diri individu dengan mendorong mahasiswa untuk menghadapi kesulitan, kekurangan, dan kesalahan yang dibuat tanpa mengkritik dirinya sendiri.

Hasil penelitian yang dilakukan Breines \& Chen (2012) memperlihatkan seseorang yang menggunakan belas kasih diri ketika menghadapi kelemahan diri akan mempunyai motivasi yang lebih besar untuk mengubah perilaku menjadi lebih baik. Ketika seseorang mengalami permasalahan, belas kasih diri membantu individu tersebut untuk dapat lebih mengenal dirinya sendiri, lebih menyayangi dirinya, sehingga akan mempermudah dalam meringankan permasalahan yang dihadapi. belas kasih diri juga meringankan rasa terpuruk hal tersebut membuat seseorang menjadi lebih terbuka pada kegagalan maupun permasalahan yang dihadapinya, sehingga seorang tersebut juga akan lebih terbuka pada lingkungan atau orang lain.

\section{Hubungan Interpersonal}

Belas kasih diri juga dapat menguntungkan hubungan interpersonal, bahwa belas kasih diri mahasiswa cenderung memiliki tujuan lebih penuh kasih dalam hubungan dengan teman yang berarti mereka cenderung untuk memberikan dukungan sosial (Crocker \& Canevello, 2008). Studi lain Neff menemukan bahwa belas kasih diri mahasiswa lebih mungkin untuk menerima dalam situasi konflik dengan orang tua entah dengan ayah, ibu atau saudara, dan pasangan hidup, sementara mereka dengan belas kasih diri yang kurang cenderung mengesampingkan kebutuhan mereka kepada pasangan.

\section{Empati}

Neff (2003) menjelaskan bahwa belas kasih diri secara signifikan terkait dengan kasih sayang, kepedulian empatik terhadap orang lain, dan altruisme. seseorang yang memiliki belas kasih diri akan lebih cenderung untuk mengampuni orang lain yang telah merugikan dirinya. Seseorang tersebut juga akan menunjukkan kebijaksanaan sehingga memiliki peningkatan keterampilan pengambilan keputusan. Individu yang memiliki belas kasih diri tinggi menunjukkan pengalaman empati yang lebih besar.

belas kasih diri menuntun individu untuk berusaha mencapai suatu kepedulian diri. Apabila individu benar-benar ingin berbuat baik kepada dirinya sendiri, individu akan melakukan hal-hal untuk membantu dirinya menjadi bahagia, seperti mengambil proyek-proyek baru yang menantang atau belajar keterampilan baru. belas kasih diri juga memberikan individu keamanan yang diperlukan untuk mengakui kelemahan sehingga individu akan mengubahnya menjadi lebih baik.

\section{Kesehatan}

Perilaku-perilaku yang berkaitan dengan kesehatan belas kasih diri juga turut berperan. Sebagai contoh, penelitian yang dilakukan oleh Adams dan Leary (2007) menunjukkan bahwa belas kasih diri dapat membantu individu bertahan dengan pola makannya. Pada individu yang menjalankan program diet sering memperlihatkan sebuah kecenderungan paradoksial seperti, jika individu tersebut gagal menjalankan 
pola makannya mereka cenderung makan lebih banyak setelahnya sebagai cara untuk mengurangi perasaan buruk yang terkait dengan kegagalan tersebut.

Sepadan dengan penelitian serupa dengan studi tersebut, Kelly, Zuroff, Foa, dan Gilbert (2009) terkait apakah belas kasih diri dapat membantu individu untuk berhenti merokok atau mengurangi. Pada penelitian ini individu dilatih untuk merasakan compassion mengenai kesulitan-kesulitan untuk berhenti merokok jauh lebih banyak daripada mereka yang dilatih untuk merefleksi. Dari hasil tersebut ternyata belas kasih diri juga efektif bagi mereka yang krisis terhadap dirinya sendiri atau penolakan perubahan.

Salah satu studi lain tentang tujuan wanita untuk berolahraga menunjukan bahwa wanita dengan self compassionate lebih memiliki motivasi instrinsik daripada ekstrinsik untuk melakukan olah raga. Mereka juga merasa lebih nyaman dengan tubuh mereka, dan lebih tidak cemas mengenai evaluasi sosial seperti penampilan fisik mereka. Oleh karena itu, belas kasih diri tampaknya meningkatkan baik kesejahteraan fisik maupun mental.

\section{Belas Kasih Diri (Self Compassion) pada Mahasiswa}

Memiliki rasa belas kasih diri pada seseorang merupakan hal yang sering terlupakan. Pada diri sendiri seseorang sering bersikap keras pada saat menghadapi keadaan yang buruk dan tak sering pula seseorang akan cenderung menyalahkan kekurangan dirinya atau beranggapan kurang adil atas kejadian yang menimpanya. Dari hal tersebut akan bermunculan emosi-emosi negatif yang cenderung akan menghambat kehidupan seseorang (Halim, 2015). emosi-emosi negatif merupakan suatu yang sering dialami oleh mahasiswa, karena mahasiswa merupakan salah satu agen perubahan yang memiliki banyak tuntutan pada saat melaksanakan studinya (Winarno, 2012).

Menurut Neff (2003) ketika seseorang lebih berbelas kasih diri atau memandang suatu keadaan dan kejadian secara objektif tanpa mengesampingkan kelemahan diri seseorang akan memiliki belas kasih diri yang tinggi. Sehingga sangat diperlukan suatu pengontrol dari emosi-emosi saat mahasiswa tengah menghadapi suatu keadaan yang buruk maupun ketika mahasiswa menjalankan tuntutan, mulai tuntutan akademik dan sosialisasi dengan teman maupun lingkungan sekitar. Selain itu memiliki sikap belas kasih juga akan membuat mahasiswa lebih memiliki motivasi dalam melaksanakan kegiatan ataupun motivasi dalam jangka panjang (Breines \& Chen, 2012).

\section{METODE PENELITIAN}

Penelitian ini menggunakan metode jenis penelitian kuantitatif deksriptif. Penelitian kuantitatif deskriptif merupakan metode yang didasarkan filsafat positivisme, dimana digunakan dalam meneliti populasi atau sempel tertentu yang kemudian dianalisis secara deskriptif menjelaskan nilai suatu variabel dengan pengumpulan data melalui instrumen (Sugiyono, 2012).

Berdasarkan dari teori tersebut maka penelitian kuantitatif deskriptif akan memperoleh data dari sampel mahasiswa pada Universitas Muhammadiyah Malang yang kemudian diolah secara metode statistik dan kemudian dijelaskan secara deskriptif dengan maksud untuk menggambarkan belas kasih diri pada mahasiswa di Universitas Muhammadiyah Malang. 
Subjek dalam penelitian ini adalah mahasiswa aktif atau yang tengah menempuh pendidikan di Universitas Muhammadiyah Malang berjenis kelamin laki-laki dan perempuan dengan rentang usia yang mulai memasuki masa remaja akhir hingga memasuki dewasa awal 17-24 tahun (Depkes, 2009).

Teknik pengambilan subjek peneliti menggunakan teknik convenience sampling yaitu skala diberikan kepada mahasiswa Universitas Muhammadiyah Malang yang bersedia untuk menjadi subjek penelitian. Populasi dalam penelitian adalah mahasiswa Universitas Muhammadiyah Malang dari data PDDIKTI tahun 2019/2020 yang berjumlah 40.876 mahasiswa. Pengambilan jumlah sampel penelitian berdasarkan pada tabel Krejcie dengan subjek berjumlah 345 orang. Berdasarkan dari tabel Krejcie dalam perhitungan jumlah sample yang didasarkan atas kesalahan 5\%, sehingga sampel mempunyai tingkat kepercayaan 95\% terhadap populasi (Sugiyono, 2012). Maka dari itu dengan jumlah sempel 345 dalam penelitian ini tentunya sudah memenuhi persyaratan atau standart operasional subjek dalam sebuah penelitian.

Variabel dalam penelitian menggunakan satu variabel yang akan dianalisis yaitu belas kasih diri (self compassion) pada mahasiswa. belas kasih diri pada mahasiswa yang dimaksud pada penelitian ini adalah sikap memiliki belas kasih dan kebaikan terhadap diri sendiri atau mahasiswa saat menghadapi berbagai kesulitan dalam hidup ataupun terhadap kekurangan dalam diri masing-masing mahasiswa dengan adanya enam komponen (selfkindess, self-judgement, common humanity, isolation, mindfulness dan over-identified).

Variabel tersebut kemudian akan di ukur menggunakan bentuk skala likert dengan instrumen pengumpulan data menggunkan alat ukur skala Self Compassion Scale (SCS) Neff (2003) yang telah diadaptasi oleh Halim (2015). SCS sendiri memiliki jumlah item 22 dengan 6 komponen yaitu, Self-kindess vs Self-judgement, Common humanity vs isolation, dan Mindfulness vs overidentification.

Pada skala Self Compassion Scale (SCS) Neff (2003) yang diadaptasi oleh Halim (2015) memiliki nilai Cronbach alpha 0.896. Selanjutnya agar skala mampu menyesuaikan kriteria dalam penelitian, maka peneliti melakukan uji coba skala terhadap 62 subjek mahasiswa yang memenuhi kriteria penelitian.

Tabel 1. Uji Validitas Instrumen Penelitian

\begin{tabular}{cccc}
\hline Instrumen & Jumlah Item Final & $\begin{array}{c}\text { Koefisien Korelasi } \\
\text { Item Total }\end{array}$ & $\begin{array}{c}\text { Koefisien } \\
\text { Reliabilitas }\end{array}$ \\
\hline SCS & 20 & $0,217-0,747$ & 0,903 \\
\hline
\end{tabular}

Tabel diatas menunjukkan hasil dari uji validitas dari 22 item skala SCS terdapat sebanyak 2 item skala yang gugur, sehingga menyisakan 20 item skala SCS yang valid. Hasil uji koefisien validitas item menggambarkan skala SCS memiliki tingkat validitas berkisar antara 0,217 - 0,747. Pada uji reabilitas instrumen SCS layak digunakan peneliti dalam melakukan penelitian ini, karena melihat angka reliabel dari instrumen $>0,60$ (Croanbach Alpha), dengan reliabilitas skala SCS sebesar 0,903.

Penelitian ini menggunakan tiga tahapan penelitian, tahapan pertama adalah tahap persiapan, dilanjutkan dengan tahap pelaksanaan, dan yang terkahir adalah tahap analisa data. Pada tahap persiapan meliputi, identifikasi fenomena, kemudian pendalaman teori, penyusunan rancangan penelitian, dan pencarian skala. Dilanjutkan dengan tahap kedua 
yaitu, tahap pelaksanaan dimulai dari penyebaran skala oleh peneliti. Penyebaran skala dilakukan secara online dengan menggunakan google form, dimana nantinya calon subjek akan diberikan kriteria di awal skala sehingga akan terseleksi subjek sesuai kriteria dalam penilaian ini. Selanjutnya subjek akan di arahkan untuk pengisian identitas berupa nama atau inisial, jenis kelamin, usia, etnis, dan fakultas/jurusan. Setelah itu subjek akan mengisi skala sesuai dengan instruksi pengisian. Tahapan yang terakhir yaitu tahap analisa data, dimana skala self compassion nanti akan di jumlah per subjeknya lalu akan ditotal seluruh skor dan kemudian ditentukan kategori menggunakan rumus kategori Cronbach Alpha milik Cronbach (1991). Selanjutnya data akan dianalisa dalam bentuk kuantitatif dan digambarkan atau dijelaskan dalam bentuk deskriptif.

\section{HASIL PENELITIAN}

Berikut penjabaran subjek berdasarkan jenis kelamin, usia, semester, dan fakultas sebagai berikut :

Tabel 2. Deskripsi Subjek Penelitian

\begin{tabular}{ccc}
\hline KATEGORI & JUMLAH SUBJEK & PRESENTASE \\
\hline Jenis Kelamin & & \\
Laki-laki & 110 & $31,9 \%$ \\
Perempuan & 235 & $68,1 \%$ \\
\hline Total & $\mathbf{3 4 5}$ & $\mathbf{1 0 0} \%$ \\
\hline
\end{tabular}

Berdasarkan tabel diatas analisa diketahui subjek dalam penelitian ini didominasi perempuan dengan jumlah 235 atau sekitar 68,1\% dan sisanya 110 atau 31,9\% adalah mahasiswa laki-laki. Selain dari data tabel diatas, doketahui juga pada usia 20 tahun merupakan usia paling banyak dimiliki subjek atau sekitar 28,7\% subjek berusia 24 tahun $(3,5 \%)$ dan usia 17 (3\%) adalah usia paling sedikit. Kemudian subjek yang mendominasi merupakan mahasiswa semester 5 dan 7 yaitu sama-sama berjumlah 99 (28,7\%). Selain itu berdasarkan fakultas dibagi menjadi 2 yaitu eksak sebanyak $104(30,1 \%)$ dan non eksak 241 $(69.9 \%)$.

Tabel 3. Belas Kasih Diri (Self Compassion) dilihat dari Jenis Kelamin

\begin{tabular}{ccc}
\hline Jenis Kelamin & Tinggi & Rendah \\
\hline Laki-laki & $58(52,7 \%)$ & $52(47,3 \%)$ \\
Perempuan & $126(53,6 \%)$ & $109(46,4 \%)$ \\
\hline
\end{tabular}

Selanjutnya pada tabel 3, self compassion dianalisa dari jenis kelamin menunjukan hasil perempuan dan laki-laki memiliki self compassion yang rata-rata masuk dalam kategori tinggi, namun pada data diatas menunjukan perempuan memiliki kategori sedikit lebih tinggi daripada laki-laki yaitu 53,6\%.

Tabel 4. Belas Kasih Diri (Self Compassion) dilihat dari Usia

\begin{tabular}{ccc}
\hline Usia & Tinggi & Rendah \\
\hline 17-20 Tahun & $80(51,6 \%)$ & $75(48,4 \%)$ \\
$21-24$ Tahun & $104(54,7 \%)$ & $86(45,3 \%)$ \\
\hline
\end{tabular}


Cognicia

http://ejournal.umm.ac.id/index.php/cognicia
ISSN 2658-8428

2020, VOL. 8, NO. 2, 234-252

Apabila dilihat berdasarkan usia subjek, Self compassion pada rentang usia 21-24 tahun sebanyak 104 subjek dengan presentase (54,7\%), sedangkan pada rentang usia 17-20 tahun sebanyak 80 (51,6\%) juga masuk dalam kategori tinggi. Lihat pada tabel 4. 
Tabel 5. Belas Kasih Diri (Self Compassion) dilihat dari Fakultas

\begin{tabular}{ccc}
\hline Fakultas & Tinggi & Rendah \\
\hline Eksak & $47(45,2 \%)$ & $57(54,8 \%)$ \\
Non Eksak & $20(51,2 \%)$ & $19(48,8)$ \\
\hline
\end{tabular}

Menurut gambaran tabel diatas, Fakultas Non Eksak masuk dalam kategori belas kasih diri (Self Compassion) tinggi 51,2\% dan pada fakultas Eksak masuk dalam kategori rendah $(54,8 \%)$.

Tabel 6. Belas Kasih Diri (Self Compassion) dilihat dari per aspek

\begin{tabular}{ccc}
\hline Aspek & Tinggi & Rendah \\
\hline Self-kindess & $190(55,1 \%)$ & $155(44,9 \%)$ \\
Self-judgement & $204(59,1 \%)$ & $141(40,9 \%)$ \\
Common humanity & $250(72,5 \%)$ & $95(27,5 \%)$ \\
Isolation items & $180(52,2 \%)$ & $165(47,8 \%)$ \\
Mindfulness & $193(55,9 \%)$ & $152(44,1 \%)$ \\
Over-identified & $186(53,9 \%)$ & $159(46,1 \%)$ \\
\hline
\end{tabular}

Selanjutnya pada tabel diatas, aspek atau komponen self compassion yang dimiliki subjek paling tinggi adalah common humanity sebesar 250 mahasiswa atau 72,5\%. Sementara aspek terendah terdapat pada aspek Self judgement $(59,1 \%)$.

\section{DISKUSI}

Berdasarkan hasil penelitian yang telah dilakukan menunjukan bahwa belas kasih diri atau Self compassion mahasiswa Universitas Muhammadiyah Malang ditinjau dari jenis kelamin laki-laki dan perempuan cenderung sama-sama memiliki rata-rata self compassion yang masuk dalam kategori tinggi. Dimana pada mahasiswa laki-laki yang masuk dalam kategori tinggi sebesar 52,7\% dan perempuan sebesar 53,6\%. Jika dibandingkan tingkat self compassion antara laki-laki dan perempuan cenderung tidak menunjukan perbedaan yang tinggi, dimana menunjukan perempuan hanya memiliki self compassion sedikit lebih tinggi dibandingkan dengan laki-laki. Temuan pada penelitian ini berbeda dengan apa yang di kemukakan Neff, (2003) yang mana perempuan cenderung memiliki self compassion yang lebih rendah dibandingkan dengan laki-laki, karena pemikiran perempuan yang jauh lebih penuh daripada laki-laki sehingga sering kali perempuan menderita depresi dan kecemasan lebih kompleks daripada laki-laki. Namun pada penelitian ini pada subjek laki-laki dan perempuan cenderung hanya menunjukan sedikit perbedaan tingkat self compassion yang dimiliki. Seperti halnya dalam penelitian Lintang (2018) dimana ditemukan derajat self campassion laki-laki dan perempuan cenderung tidak menunjukan perbedaan yang menonjol. Artinya keberagaman respon terhadap kejadian-kejadian negatif antara subjek laki-laki dan perempuan cenderung tidak menampilkan perbedaan yang kontras. Selain itu pada penelitian Missiliana (2014) juga menggambarkaan pada aspek common humanity dan mindfulness perempuan cenderung lebih tinggi daripada laki-laki. Tuntutan suatu budaya sering kali mengharuskan perempuan cenderung untuk lebih mengasihani atau lebih memperhatikan orang lain, sehingga perempuan tidak akan mengabaikan pada seorang yang mengalami penderitaan atau kesusahan dan akan lebih mau untuk berbagi dalam penderitaan dengan berpandangan secara objektif dan realistis. Dari hal tersebut searah juga dengan desertasi Pommier (2010), bahwa perempuan diprediksi memiliki compassion yang 
lebih tinggi dari laki-laki, karena perempuan lebih berempati terhadap orang lain daripada laki-laki, dan empati merupakan konsep yang memiliki kaitan dengan compassion sehingga tidak menutup kemungkinan self compassion pada perempuan akan lebih tinggi.

Selanjutnya pada hasil penelitian diatas didapatkan bahwa pada rentan usia mahasiswa mulai dari 18-24 diketahui masuk dalam derajat self compassion berkategori tinggi dan pada usia 17 dan 19 tahun masuk dalam kategori rendah. Searah dengan penelitian yang dilakukan Neff dan Vonk (2009) bahwa self compassion terasosiasi secara signifikan dengan tingkat usia. Dimana dijelaskan semakin tinggi tingkat usia maka akan semakin tinggi pula taraf dari self compassion yang di miliki individu. Individu akan mencapai tingkat self compassion yang tinggi apabila telah mencapai tahap integrity karena lebih pada tahap tersebut individu akan bisa menerima dirinya secara lebih positif.

Kemudian rentan usia 21-24 pada penelitian ini memiliki kategori self compassion presentasi sedikit lebih tinggi, karena pada usia tersebut mahasiswa memasuki semester 7 atau semester lanjut. Sama halnya dengan hasil penelitian yang di lakukan oleh Siswati (2017) menggambarkan mahasiswa semester 6 atau lanjut memiliki tingkatan self compassion yang tinggi. Hal tersebut menunjukan bahwa mahasiswa pada semester lanjut memiliki tuntutan akademik yang tinggi seperti, skripsi dan tugas-tugas akhir. Germer (2009) mengutarakan bahwa self compassion adalah suatu penerimaan diri disaat individu sedang mengalami suatu penderitaan. Sejalan juga dengan penelitian dari Lutz, Greischar, Rawlings, Ricard, dan Davidson (2004) self compassion pada individu berhubungan dengan aktifitas otak yang tinggi pada prefrontal kortek bagaian kiri atau bagian yang berhubungan mengatur kebahagiaan dan optimisme. Sehingga individu dengan self compassion akan mengurangi dampak peristiwa-peristiwa negatif dalam kehidupan. Dari penelitian Neff, Rude, dan Kirkpatrick (2007) juga menunjukkan individu dengan self compassion secara signifikan memiliki suasana hati yang lebih positif dan cenderung merasakan sedikit suasana hati negatif sewajarnya.

Pada analisa aspek pertama self compassion, Self-kindess yaitu kemampuan individu untuk memahami dan menerima diri apa adanya serta memberikan kelembutan, tidak menyakiti atau menghakimi diri sendiri berada di kategori tinggi. Hal tersebut menunjukan mahasiswa mayoritas ketika mengahadapi suatu permasalahan atau penderitaan akan merespon dengan sewajarnya dan tidak akan cenderung menyalahkan diri atau menghakimi diri dengan keras. Seperti dalam pendapat Neff (2011) Self-kindness akan memungkinkan individu merasa aman seperti ketika mengalami pengalaman yang menyakitkan dan tidak akan menghakimi diri atas kejadian atau keadaan. Namun aspek ke dua atau sisi lain dari Self-kindess yaitu Self-judgement sikap menghakimi diri sendiri secara keras, mahasiswa juga masuk dalam kategori tinggi sehinggi kemungkinan juga ketika mahasiswa kurang bisa mengontrol keadaan atau penderitaan itu juga akan muncul kemungkinan untuk bersifat keras pada dirinya sendiri.

Selanjutnya pada aspek ketiga yaitu Common humanity dan aspek keempat Isolation menunjukan mahasiswa memiliki Common humanity dan juga isolation yang masuk dalam kategori tinggi. Bisa dikatakan mahasiswa akan memandang suatu kegagalan dan kesulitan merupakan bagian dari kehidupan dimana semua orang juga akan mengalaminya. Menurut Neff, (2009) individu yang merasa isolation (sisi lain dari common humanity) cenderung akan memiliki pandangan sempit pada kesulitan, tantangan, dan kegagalan sehingga akan berfokus pada ketidaksempurnaan diri, sehingga ketika mengalami suatu keadaan buruk 
atau kesulitan cenderung tidak akan berfokus pada ketidak sempurnaan diri dan perasaan terisolasi pada keadaan tersebut. Salain itu menurut Missiliana (2014) aspek common humanity juga dapat meningkatkan aspek lain dari dari self compassion seperti self-kindness dan mindfulness pada individu.

Pada aspek terakhir yaitu mindfulness dengan over-identified dihasilkan aspek mindfulness berada pada kategori tinggi. Menurut Hidayati (2013) konsep utama mindfulness adalah melihat sesuatu seperti apa adanya, tidak ada penambahan maupun dikurangi, sehingga respon-respon yang dihasilkan dapat lebih efektif. Mindfulness pada mahasiswa akan dapat sepenuhnya mengetahui dan mengerti apa yang sebenarnya mereka rasakan dirasakan. Selanjutnya interaksi antar aspek Self compassion yang dimiliki mahasiswa menggambarkan ketika tengah mengalami suatu permasalahan mahasiswa akan memandang suatu keadaan itu dengan sebagaimana mestinya dan apa adanya karena mahasiswa dengan common humanity akan memandang penderitaan merupakan hal yang umum terjadi atau wajar jika dialami oleh semua orang sehingga akan cenderung meningkatkan self-kindess seperti memperlakukan diri sendiri dengan baik dan kelembutan tanpa adanya rasa menyalahkan diri sendiri maupun kekurangan diri.

Hasil ini menggambarkan bahwa saat mahasiswa dapat memandang suatu kegagalan atau penderitaan yang dialaminya adalah hal yang wajar dan manusiawi, maka mahasiswa pun dapat memandang kegagalan dan penderitaan orang lain sebagai suatu kewajaran juga dan pada umumnya akan dialami oleh semua orang. Cara pandang ini membantu mahasiswa untuk bersikap memahami, mengesampingkan perbedaan, melihat kekurangan secara menyeluruh, tidak hanya menyalahkan keadaan dan diri sendiri sehingga akan lebih menumbuhkan kesejahteraan. Penelitian yang di lakukan Neely, Schallert, Mohammed, Roberts, \& Chen (2009) menunjukkan self compassion berpengaruh pada sesejahteraan pada mahasiswa dan akan lebih mengurangi tingkat stres dan emosi-emosi negatif lainnya pada mahasiswa. Selain itu self compassion yang tinggi juga akan membangun suatu hubungan sosial yang baik. Seperti dalam Neff, Pisitsungkagarn, \& YPHsieh (2008) menyatakan individu dengan self compassion akan lebih bersikap baik pada orang lain.

Keterbatasan dalam penelitian ini adalah kurang luas dalam pengambilan subjek karena hanya berpaku pada mahasiswa Universitas Muhammadiyah Malang. Hal tersebut dikarenakan untuk mengetahui secara belas kasih diri (self compassion) pada mahasiswa menyeluruh maka harus melibatkan dari keragamanan mahasiswa juga sehingga faktorfaktor yang lain juga dapat teranalisa. Sedangkan kelebihan dari penelitian adalah belum ada gambaran belas kasih self compassion khususnya pada mahasiswa di suatu universitas tertentu, sehingga hasil dalam penelitian ini diharapkan dapat menjadi suatu wawasan untuk mahasiswa untuk selalu menjaga sikap belas kasih diri.

\section{SIMPULAN DAN IMPLIKASI}

Berdasarkan hasil penelitian yang telah dilakukan dapat ditarik kesimpulan tingkat belas kasih diri (self compassion) mahasiswa Universitas Muhammadiyah malang masuk dalam kategori tinggi. Dimana antara mahasiswa laki-laki dan perempuan memiliki self compassion sama-sama masuk dalam kategori tinggi. Diartikan mahasiswa pada penelitian ini dapat mengatasi situasi dalam diri dengan tidak menyalahkan dan memandang suatu keadaan dengan apa adanya tanpa ada rasa menghakimi. Hal tersebut membuat mahasiswa lebih tangguh dalam menghadapi tuntutan-tuntutan yang ada sehingga akan meningkatkan akademik maupun kesejahteraan dari mahasiswa. Rentang usia mahasiswa memiliki 
presentase self compassion dalam kategori tertinggi adalah pada 21-24 dimana usia tersebut mayoritas masuk dalam semester tengah hingga akhir. Selain itu, aspek tertinggi dimiliki subjek adalah Common humanity.

Implikasi dari penelitian ini untuk mahasiswa selalu menjaga dan meningkatkan kualitas sikap belas kasih (self compassion). Guna untuk meningkatkan kualitas self compassion mahasiswa perlu untuk mempertahankan dan meningkatkan mindfulness, serta mengasah lebih baik lagi kemampuan self kindness dan common humanity. Selanjutnya strategi yang dapat digunakan sepeti memanfaatkan dukungan sosial yang ada, terutama dukungan yang sifatnya lebih signifikan berpengaruh pada diri sendiri. Hal tersebut akan berpengaruh dalam menghadapi tuntutan menjadi seorang mahasiswa dan meningkatkan akademik dan keadaan-kedaan negatif dapat teratasi dengan baik sehingga kesejahteraan akan lebih baik. Selanjutnya untuk instansi dan birokrasi agar mempertahankan kegiatankegiatan yang sifatnya bersifat sosial dan menambahkan kegiatan yang sifatnya interaktif dukungan individu satu dengan lainnya. Selain itu membuat program untuk mengatasi emosi-emosi negatif sepeti kegiatan meditas, atau pengajaran tentang penanggulangan emosi negatif. Bagi peneliti selanjutnya diharapkan untuk menggunakan subjek dengan karakteristik lebih khusus seperti membandingkan budaya A dengan budaya lain. Selain itu seperti mempertimbangkan peran dari tiap-tiap gender sehingga dapat menunjukan gambaran atau faktor yang lebih detail.

\section{REFERENSI}

Allgower, A., Wardle, J. \& Steptoe, A. (2001) Depressive symtoms, social support, and personal health behaviors in young men and women. Health Psychology, 20, (3), 223227.

Asiyah, N. (2013). Pola asuh demokratis, kepercayaan diri dan kemandirian mahasiswa baru. Jurnal Psikologi Indonesia, 2, (2), 108 - 121.

Boute, V. M., Pancer, S. M., Adams, G., Pratt, M. W., Lefcovitch, S. B., Polivy. J., \& Wintre, M. G. (2007). The importance of friends: Friendship and adjustment among 1st-year university students. Journal of adolescent research, 22, (6), 665-689.

Breines, J. G., \& Chen, S. (2012). Self-compassion increase self-improvement motivation. Personality and Social Psychology Bulletin, 38, (9), 1133-1143.

Brown, K. W., \& Ryan, R. M. (2003). The benefits of being present: Mindfulness and its role in psychological well-being. Journal of Personality $\mathcal{E}$ Social Psychology, 84, 822-848.

Crocker, J., \& Canevello, A. (2008). Creating and undermining social support in communal relationships: The role of compassionate and self-image goals. Journal of Personality and Social Psychology, 95, 555-575.

Cronbach, L. J. (1991). Methodological study-a personal retrospective, in Brennan, Robert, L., 2001, an essay on the history and future of reliability from the perspective of replications. Journal of Educational Measurement, 38, 387-390.

Cynthia, Trida., \& Anita, Z. (2009). Kecenderungan depresi pada mahasiswa dan perbedaan berdasarkan jenis kelamin. Jurnal psikologi Gunadarma, 3, 68-70.

Depkes, R. I. (2009). Profil kesehatan Indonesia. Jakarta: Depkes RI.

Germer, C. K. (2009). The Mindful Path to Self-Compassion: Freeing Yourself from Destructive Thoughts and Emotions. New York: The Guilford Press. 
Gillbert, P., dan Procter, S. (2006). Compassionate mind trainning for people with hight shame and self-critism: Overview and pilot study of a group therapy approach. Clinical Psychology and Psychotherapy, 13, (6), 353-421.

Halim, A.R. (2015). Pengaruh self compassion terhadap subjective well being pada mahasiswa asal luar jawa tahun pertama universitas negeri semarang. Skripsi, Jurusan Psikologi Fakultas Ilmu Pendidikan Universitas Negeri Semarang.

Hidayati, D. S. (2015). Self compassion dan loneliness. Jurnal Ilmiah Psikologi Terapan, 3, (1), 2301-8267.

Hidayati, F. (2013). Self-compassion (Welas Asih); Sebuah alternatif konsep transpersonal tentang sehat spiritual menuju diri yang utuh. Jurnal Spiritualitas dan Psikologi Kesehatan.

Hurlock, B. E. (2006). Psikologi perkembangan. Jakarta: Erlangga.

Kacen, J. J., \& J. A. Lee. (2000). The influence of culture on consumer impulsive buying behaviour. Journal of Consumer Psychology, 12, (2), 163-176.

Krisdianto, M.A \& Mulyanti. (2015). Mekanisme koping berhubungan dengan tingkat depresi pada mahasiswa tingkat akhir. Journal ners and midwifery indonesia, 3, (2).

Legiran, M.Z.A., Nedya, B. (2015). Faktor risiko stres dan perbedaannya pada mahasiswa berbagai angkatan di fakultas kedokteran universitas muhammadiyah palembang. Jurnal kedokteran dan kesehatan, 2, (2), 197-202.

Lintang, H.M. (2018). Analisa pengaruh self-compassion dan social support terhadap resiliensi diri anggota paduan suara mahasiswa gema gita bahana uin malang. Skripsi, Universitas Islam Maulana Malik Ibrahim Malang.

Lutz, A., Greischar, L. L., Rawlings, N. B., Ricard, M., \& Davidson, R. J. (2004). Long-term meditators self-induce high-amplitude gamma synchrony during mental practice. Proceeding of the National Academy of Sciences of the United States of America. 101, (46), 16369-16373. doi:10.1073/pnas.0407401101.

Martin, R.C., \& Dahlen, E. R. (2005). Cognitive emotion regulation in prediction of depression, anxiety, stress, and anger. Personality and Individual Differences. 39, 12491260.

Michael, K.D., Huelsman, T.J., Gerard, C., Gilligan, T. M. \& Gustafson, M.R. (2006). Depression among college students: Trends in prevalence and treatment seeking. Counseling and Clinical Psychology Journal, 3, (2), 60-70.

Missiliana, R. (2014). Self-compassion dan compassion for others pada mahasiswa fakultas psikologi uk.maranatha. Laporan Penelitian.

Neely, M. E., Schallert, D. L., Mohammed, S. S., Roberts, R. M., Chen, Y. (2009). Self-kindness when facing stress: the role of self-compassion, goal regulation, and support in college students' well-being. Journal of motivation and emotion, 33, 88-97, DOI: 10.1007/s11031-008-9119-8.

Neff, K. D. (2011). Self Compassion: Stop Beating Yourself Up and Leave insecurity behind. Texas: Harper Collins Publishers.

Neff, K \& McGehee, P. (2009). Self-Compassion and psychological resilience among adolescents and young adults. Psychological Press.

Neff, K., Pisitsungkagarn, K., \& Hsieh, Y. P. (2008). Self-compassion and self-construal in the united states, thailand, and taiwan. Journal of Cross-Cultural Psychology, 39, 267-285.

Neff, K., Kirkpatrick, K. L., \& Rude, S. S. (2007). Self-compassion and adaptive psychological functioning. Journal of Research in Personality, 41, 139-154. 
Neff, K. D. (2003). Development and validation of a scale to measure self-compassion. self and identity, 2, 223-250.

Pommier, E.A. (2010). Development of a scale to measure compassion. Desertasi, The University of Texas at Austin.

Qonitatin, Novi., Sri, W., Gusti, Y.A,. (2011). Pengaruh katarsis dalam menulis ekspresif sebagai intervensi depresi ringan pada mahasiswa. Jurnal Psikologi Undip, 9, (1).

Reyes, D. (2011). Self Compassion: A concept analysis. Journal of Holistic Nursing, 30, (2), 8189.

Santrock,W. J. (2007). Remaja edisi sebelas jilid dua. Jakarta: Erlangga.

Seswita, P. (2013). Hubungan antara dukungan sosial dengan resiliensi dalam menghadapi stres akademik pada mahasiswa upi perantau. Skripsi, Universitas Pendidikan Indonesia.

Siswati, F.N.R.H. (2017). Hubungan antara self-compassion dan efikasi diri pada mahasiswa yang sedang menyelesaikan tugas akhir. Jurnal Mediapsi, 3, (2), 22-28.

Sugiyono. (2012). Metode penelitian kuantitatif kualitatif dan RED. Bandung: Alfabeta.

Waskito, P., Loekmono, J. T. L., \& Dwikurnaningsih, Y. (2018). Hubungan antara mindfulness dengan kepuasan hidup mahasiswa bimbingan dan konseling. Jurnal Kajian Bimbingan dan Konseling, 3, (3), 99-107.

Werner, K.H., Jazaieri, H., Goldin, P.R., Ziv, M., Heimberg, R., \&Gross, J.J., (2012). Selfcompassion and social anxiety disorder. Anxiety, Stress and Coping, 25, (5), September, 543-558.

Winarno, B. (2012). Kebijakan publik teori, proses dan studi kasis. Yogyakarta: CAPS. 